\title{
The impact of corruption and local content policy in on firm performance: evidence from Kazakhstan
}

Article

Accepted Version

Creative Commons: Attribution-Noncommercial-No Derivative Works 4.0

Kalyuzhnova, Y. and Belitski, M. (2019) The impact of corruption and local content policy in on firm performance: evidence from Kazakhstan. Resources Policy, 61. pp. 67-76. ISSN 0301-4207 doi:

https://doi.org/10.1016/j.resourpol.2019.01.016 Available at https://centaur.reading.ac.uk/81882/

It is advisable to refer to the publisher's version if you intend to cite from the work. See Guidance on citing.

To link to this article DOI: http://dx.doi.org/10.1016/j.resourpol.2019.01.016

Publisher: Elsevier

All outputs in CentAUR are protected by Intellectual Property Rights law, including copyright law. Copyright and IPR is retained by the creators or other copyright holders. Terms and conditions for use of this material are defined in the End User Agreement.

www.reading.ac.uk/centaur 
Central Archive at the University of Reading

Reading's research outputs online 


\title{
The Impact of Corruption and Local Content Policy in on Firm Performance: Evidence from Kazakhstan
}

\begin{abstract}
Many governments of both resource-rich and resource-poor countries have recently started to use local content policies as a tool in their industrial policies. However, careless implementation of local content policies can lead to corrupt practices and threaten firm performance. Using the World Bank Enterprise Survey of 933 Kazakhstani firms in 2009 and 2013, we study the effect of corruption on employment and sales growth and the role that explicit local content policy plays in this relationship. Our findings demonstrate that corruption has "a greasing the wheels effects", facilitating employment growth and sales growth in Kazakhstani firms. In case of securing a government contract, corruption will have a larger effect on sales growth than on job growth. This study provides insights and implications for contract law and industrial policy in Kazakhstan.
\end{abstract}

Keywords: corruption, local content; firm performance; policy; Kazakhstan JEL classification: D23, L25, L52, K42, O1

\section{Introduction}

Many governments of both resource-rich and resource-poor countries have recently started to use local content policies (LCPs) as a tool in their industrial policies. There is no universally agreed definition of local content (LC), and every country has its own definitions, emphases and variations depending on the period of policy implementation and the stage of economic development (Kalyuzhnova et.al. 2016). Kolstad and Kinyondo (2017) define LC as "the incidence of domestic inputs in the various parts of a value chain" (Kolstad and Kinyondo 2017:411). Therefore, overall, LCPs aim to increase in-country value (Ovadia 2012) by enabling domestic producers to expand their activities, compete with imports and add more value to their products (Kalyuzhnova et al. 2016). LCPs are government-led policies that often 
promote, support and provide privileges to local companies (Ovadia 2014). Overall, LCPs are perceived as a way of promoting economic and social development.

However, careless implementation of LCPs can lead to corrupt practices. Officials may overstep their authority and use their influence to implement the established Local Content Requirements (LCRs) to benefit their interests (or those of their allies/their family members, etc.), inciting other players (e.g. international companies) to bribe the authorities. To date, the literature on links between LCPs and corruption vulnerabilities is limited (Martini 2014; Nwapi 2015). However, even from these limited sources it is evident that in order to prevent and curb corruption in LCR it is important to establish a set of measures which would enhance transparency and accountability in conducting such LCPs (e.g. including anti-corruption clauses into agreements/licenses).

Unfortunately, LCPs, transparency and governance are not well-linked in the literature. Such a disconnect is unfortunate, considering the crucial influence of these factors on the successful implementation of LCPs. In order to achieve greater firm performance through the introduction of LCPs, it is important to take into account the microfoundations of corruption. (Tonoyan, et.al. 2010; Sarsfield, 2012).

We define corruption as the use of public office for personal gain (Rose-Ackerman and Palifka 2016) and more broadly as suggested by Lambsdorff (2002) and Aidt (2016: 145): "as a special means by which private agents may seek to pursue their interest in competition for preferential treatment by government officials or politicians and where the "means" are valued by the recipient" (Aidt 2016:145). Examples of "special means" may include contracts and licenses, procedures, permissions and minimum LCRs.

Some literature shows a positive impact of corruption on firm performance, especially with firms that do not face significant competition (Athanasouli et al. 2012; Sahakyan and Stiegert 
2012). Other literature shows a negative impact (Treisman 2000; McArthur and Teal 2002; Glaeser and Saks 2006; Hallward-Driemeier et al. 2006; Dutta and Sobel 2016). Most of these studies treat corruption as a business environment using country-level indicators of corruption instead of firm-level indicators.

In this paper we argue that the impact of corruption on firm performance is determined by both explicit LCPs and an economic environment with a mix of formal and informal institutions (Williamson 1998). While prior work on the causes of corruption (Tonoyan, et.al. 2010) and LCP (Nwapi, 2015) has been done on the macro level, our study examines micro foundations of corruption and firm performance. This approach helps to understand how firms behave at the micro level and how exactly corruption and LCP are associated with firm performance.

To explore this issue, we employ firm-level data from the World Bank Enterprise Survey on 933 Kazakhstani firms over the period 2009 to 2013, namely, firm characteristics that include engagement with local authorities and adjustment to regulation and government programmes, such as LCPs. However, LCPs and bureaucracy factors have rarely been incorporated into empirical studies, particularly in studies of emerging economies (Kalyuzhnova et al. 2016).

The choice of Kazakhstan was determined for a number of reasons: the country has adopted aggressive and restrictive LCPs; it experienced growth in firm formation during the transition period between 1999 and 2007 (An et al. 2017); high levels of inequality in market access encourage substantial involvement of firm representatives with authorities to smooth the entry and enhance firm performance (Aidis, et.al. 2012); and well-documented data on the country is available from the World Bank Survey and macro-economic regulation. That said, the phenomena identified here are also likely to be found in other countries through the use of firm- 
level data and measures in order to capture the impact of corruption on firm performance under various regulation modes (i.e. LCPs).

This study provides a critical test which is based on a literature (Djankov et al. 2002 and Kalyuzhnova et al. 2009) that analyses the impact of corruption and LCPs on firm performance. The study also offers new perspectives for the development of policies supporting LC development. In particular, this paper emphasises the importance of the link between corruption and LCPs in various measurements of firm performance, namely: employment growth and sales growth.

By introducing LCPs into the public economic literature, we achieve three important contributions.

Our first contribution is built on institutional literature (Djankov et al. 2002). From the perspective of LCPs (Flaig and Stone 2017), we provide an empirical test of the effect of corruption on various measurements of firm performance, and of the role that LCPs play in this relationship.

Our second contribution, through the examination of this relationship, is to establish that LCPs mitigate the relationship between corruption and sales growth. Finally, we discuss transparency and governance in the context of LCPs (Kalyuzhnova et al. 2009, 2016; Ovadia 2014).

Our key findings confirm that corruption has both "greasing and sanding the wheels of business effects", facilitating employment growth whilst hampering productivity in Kazakhstani firms. We respond to a call in institutional and economic systems literature for a more nuanced analysis of how firm performance is influenced by corruption and LCPs (van Stel et al. 2007; Djankov 2009, Kalyuzhnova et.al. 2009). We find that corrupt behavior is facilitated by LCPs in Kazakhstan and we provide answers to the question of whether building 
relationships with authorities changes firm performance. Although our findings are related to Kazakhstan, our conclusions are likely to be applicable to other resource-rich emerging countries pursuing LCPs.

The implications for policy are as follows. We argue that improvements in regulation are required in order to achieve greater transparency and governance in LCPs, as these are crucial factors for the successful implementation of such policies. A dedicated state agency should have as special remit, with a public mandate, the monitoring, evaluation and enforcement of compliance.

The paper is structured as follows. In the next section (Section 2), we discuss the evolution of LCPs in Kazakhstan and its specifics. Section 3 provides the theoretical framework. Section 4 sets up an empirical model, and describes the dataset. Section 5 reports our main results. Section 6 concludes.

\section{Local content policies in Kazakhstan}

From the beginning of independence, the Kazakhstani government has aimed to create jobs and to create an environment promoting Kazakhstani (local, by origin) businesses in specific sectors. However, in the early 1990s, the foreign firms had a significant dominance over the industrial and service sectors of the hydrocarbon industry of Kazakhstan, where the mode of operation was based on an "expatriate" basis (both in terms of human resources and manufacturing facilities, which were exported from abroad). (Kalyuzhnova 2008)

This situation continued for most of the decade, leading the Kazakhstani government to seek ways of boosting LC through legislation, in order to develop the industrial capacities of the local economy. Although Kazakhstan's LCPs first appeared with the Petroleum Law of 1995, the first concrete step was made in the 2000s: "the Registry of Domestic Producers and Foreign Investors was developed to provide local producers the opportunity to understand the 
potential demand and to act accordingly in their investment decisions and upgrades" (Kalyuzhnova et.al. 2016:108). The basis of such policy was government pressure on international energy companies working in Kazakhstan to build up local capabilities via subcontractors and services. The 1996 Law on Subsurface and Subsurface Use required companies to propose, from the initial stage, their own LC commitments, namely quantitative indicators $(\%)$ of local workers to be employed, procuring products and services of Kazakh (or Kazakhstani) origin, and commitment to social projects (e.g. improving infrastructure or contributing to the economic and social development of their region of operation). However, this approach was not successful, since subsoil users subverted or bypassed LCRs.

From 2001, LCRs were promoted by the government through a number of laws, decrees and labour quotas. In addition, the government was obliging companies to invest in regional social projects. On 1 December 2004, the terms "Kazakh manufacturer", "Kazakh origin" (goods, works and services (GWS) of Kazakh origin), "Kazakh content" were introduced into the subsoil legislation, as part of a governmental review of the LCPs framework. More specific LCPs were laid out in the 2005 Law Concerning Production Sharing Agreements when Conducting Offshore Petroleum Operations. This law required that KMG (KazMunayGaz, the national oil company) hold at least a 50\% share of new Production Sharing Agreements, and defined specific requirements to ensure purchase of local goods and services.

However, until the end of 2009, the LCP in Kazakhstan was more a statement of intent than robust policy. For instance, even though the rules for purchasing GWS by subsoil users were first approved by the Kazakhstani Government Decree in 2002, "the majority of subsoil users did not actually apply these rules and kept purchasing GWS at their discretion" (Kalyuzhnova et.al 2016:109). December 29, 2009, saw the adoption of the Law on Amendments to Some Legislative Acts on Kazakh Content; in 2010, further evolution of LC took place with 
significant regulatory change represented by the introduction of the new Law on Subsurface and Subsurface Use (2010).

LCPs (although still focusing on local labour and procurement) were thus "shifted toward the overarching objective of economic diversification and the reduction of economic dependency on the oil sector" (Tordo and Anouti 2013:114). The government had introduced clear targets, procurement rules, and strict measurement procedures. The spillover of such policies was felt on all sectors of the economy.

Prequalification of potential suppliers is an independent audit of potential suppliers, which allows to assess the supplier's ability to perform work, provide services and deliver goods, and also protect from the participation of other firms. Currently 600 Kazakhstani companies have been prequalified. As a part of the pilot project, 64 items of goods, works and services have been identified, for which since April 3 of this year, procurements have been made only among prequalified suppliers. The listed potential suppliers are exempt from payment of the tender application fees, confirmation of staff qualifications and work experience, as well as notarization of documents within 2-3 years. In addition, an independent evaluation gives companies point-wise recommendations for improving their operations.

The existing LCPs have only partially achieved their purposes. Localization of workforce policy has indeed pushed the companies to use more local labour force and to invest in their upscaling, but with regards to procurement and the competitiveness of Kazakhstani companies the situation is more complex. Domestic sourcing of GWS proved to be extremely difficult. For example, under the procurement rules, subsoil users are obliged to announce forthcoming purchases, tender documentation, etc., and post their results on an online registry of GWS. Since Kazakhstan's domestic capacity remains low, international technical expertise and capital is required. 
In 2015 Kazakhstan jointed WTO. Under WTO regulations, in particular GATT and TRIMS, LCR in the form of mandatory sourcing of inputs is explicitly prohibited. However, a series of exemptions exists relating to government procurement, the encouragement of technology transfer and for least developed countries (Ramdoo 2015). The WTO agreement, ratified by Kazakhstan, establishes a transition period for full implementation of WTO requirements until 1 January 2021. Following the transition period all measures of support and LCRs in the subsoil contracts are to be abolished. Subsidies connected with export and import substitution will be prohibited upon the agreement coming into legal force and all LCRs on procurement of goods and services (for commercial use) are to be abolished. Accession to the WTO potentially signals the beginning of a new approach to industrial policy in Kazakhstan, e.g. the effect of this policy on LCRs by companies affiliated with Joint Stock Company (JSC) Samruk-Kazyna should change the company's perceptions of competitiveness (without protectionist measures), as well as testing the effectiveness of the functioning of these enterprises. Since Subsoil Law (1996), LC has been an evolving and increasingly important element of Kazakhstan's approach to natural resource management. From 2021 such policies are to be abandoned. WTO membership thus redefines the parameters for industrial policy in Kazakhstan.

The precise impact of WTO membership on industrial policy remains, however, to be seen. LCR are only weakly enforced by the WTO (Ramdoo 2015) and the experience of other resource rich economies, such as Norway, suggests that alternative policies can be implemented to achieve similar goals.

At the present time, however, these outcomes remain speculative. Formally Kazakhstan's oil and gas sector has a finite period to impose protectionist measures to develop domestic (infant) industries, facilitate sectoral catching-up and incentivize the competitiveness of the sector. Will the 2010 Subsoil and Subsoil users Law in Kazakhstan, which establishes the 
principle of blanket minimum LCR for new concessions, be successful in its aim to diversify the industrial sector and encourage the development of small and medium enterprises to international standards, thus ultimately improving the country's competitiveness by 2021 ? Over the recent past, Kazakhstan's competitiveness index has improved; the country was ranked $42^{\text {nd }}$ out of 140 countries in Schwab and Sala-i-Martín (2015). However, measures of the business environment still suffer from concerns about corruption and rule of law providing security of property rights.

To sustain its position and to improve further, the country needs to look at the particular pillars that determine the success or failure of the governmental economic policy. Until 2021 this will include both protectionist measures (in the form of LCRs) and competition policy. Would the LCP, restricted under WTO rules, make a difference to overall Kazakhstani competitiveness? The experience of other resource rich countries demonstrates that in some cases LCPs can stimulate domestic product development and exports; other cases have established that the LCRs can become an impediment to competitiveness, for instance when a country's innovation system fails to facilitate innovation-led growth adequately, or when implementation inhibits competition. Experience with LCPs also demonstrates that despite ambitions to terminate LCRs, in accordance with timelines embodied in WTO agreements or other international treaties, some resource-rich countries support/promote LCPs beyond the agreed dates. In such cases the form, term and strategy undergo changes, but the extraction-led domestic value-added production remains essentially the same. Kazakhstan would need a rigorous analysis of the current situation, acknowledging the constraints of the time frame with realistic expectations of what could be done with the momentum of the last LCPs.

\section{Theoretical framework}

\subsection{Corruption and firm performance}


Corruption and procedural bureaucracy are known to negatively affect firm performance and limit access to the markets (North 1990). Literature on corruption also claims that adjustment to regulation formally and informally improves inefficiencies (Spiller 1990) in countries with weak institutions. The variation of firm performance is conditional upon the relations between business and the government authorities (Hellman et al. 2003). Firms which face a high administrative burden may seek help from corrupt government officials in order to increase their economic activity (Dutta and Sobel 2016).

Although an environment with many long bureaucratic procedures affects entrepreneurial opportunities and decreases returns, firms that manage to establish the efficient "means" of dealing with regulation by engaging in a variety of networking practices with authorities perform better (Aidis et al. 2012). In "grabbing hand" situations, the literature suggests that corrupt government officials create rents which they extract for themselves through the introduction of "artificial scarcity via licenses, permissions, cumbersome procedures, etc" (Aidt 2016: 151).

Unwillingness to engage in networks and build relationships with authorities may act as a barrier to survival and growth. World Bank Enterprise Survey illustrated that in Kazakhstan, the top two obstacles for the small firms are corruption and practices of informal sector; for medium firms - tax rate and corruption; for large firms - inadequately educated workforce and practices of informal sector. (World Bank 2013). Therefore, the firms will attempt to alleviate these obstacles by collaborating and negotiating business conditions with authorities in order to get access to internal information about the timing and changes in regulation. (Søreide 2002).

The literature on rent-seeking suggests that corruption can pave the way to avoid an inefficient regulatory environment, in particular in emerging and developing economies ("helping hand" type of corruption) (Becker and Stigler 1974, Wieneke and Gries 2011; 
McArthur and Teal 2002). There is an argument that in countries where corruption is expected in every transaction (Meon and Sekkat 2015), the expectation ameliorates the 'arbitrariness' of corruption and greases the wheels of business. In the rent-seeking literature the rents are often perceived as given (Rose-Ackerman and Palifka 2016). Corruption affects firm performance across different firm-sizes (Mendoza et.al. 2015), with larger firms potentially benefiting more from rent-seeking behaviour than smaller firms.

Contemporary literature finds insufficient link between corruption and low productivity (Lambsdorff 2003), and demonstrates that some firms could be more productive than others. For example, exporters tend to be larger and more productive than non-exporters. Some evidence suggests that in regions where there is a scope for corruption in the process of obtaining export licenses or regulations related to exports, these exporter premia are smaller than in regions without such scope (Francis and Schweiger 2017).

Some studies perceive corruption as a "greasing the wheels mean", with corruption helping to overcome bureaucratic constraints and rigid regulations and requirements (Lein 1986), in particular in a weak institutional environment (Acemoglu and Verdier 2000, Meon and Weill 2010). Djankov et al. (2002) introduced the tollbooth hypothesis, which suggested that higher procedural bureaucracy leads directly to increased corruption as government officials offer to "grease the wheels" in return for financial compensation. Supporters of the concept of efficient corruption argue that the ability to comply with the administrative and financial burden, which may result in corrupt officials, can "grease the wheels" of the regulatory system and facilitate firm performance. Therefore, we hypothesize:

H1: Firm corruption increases firm performance.

\subsection{Local content policy, corruption and firm performance}

The government authorities responsible for LCPs implementation often use their own discretion, combined with a lack of transparency. This results in uneven implementation and 
enforcement of LCRs (Kalyuzhnova 2008). LCPs are not approached uniformly in all countries. In some countries, there are clear stipulations (explicit LCPs) on the minimum level of LCR that firms must embrace (even in the strict quantitative terms). This is especially the case in countries with local content legislation and rigid prescriptions, e.g. Nigeria, Angola, etc. In other countries, there are not such clear stipulations (implicit LCPs) and the policies are less prescriptive and less formal. In countries with explicit LCPs, in order to win contracts, the firms are required by the authorities to demonstrate in their bids a high level of LCRs compliance. In countries with implicit LCPs the share of LC in value added becomes a subject of negotiation/bargaining between the government and a firm, e.g. Russia, UK. (Kalyuzhnova et al. 2016).

The LCPs are likely to create more opportunities for corruption (Belitski et al. 2016) as regulation may be formulated in a way that keeps the door open for further negotiations, particularly when the LCRs are subject to changes.

We build on Bicchieri and Duffy (1997), Bicchieri and Rovelli (1994) in explaining the role of the LCPs in facilitating "greasing the wheels" of business through corruption (Lien 1990; Kaufmann and Wei 2000; Meon and Sekkat 2015).

It is expected that the LCPs should promote and facilitate higher participation of small and medium firms and ultimately enhance industrial development. In the protected environment, the domestic firms would be able to identify existing opportunities and build a successful niche business (Heum et al. 2003).

It is important to understand the impact of the explicit LCPs implementation in facilitating firm performance and building a relationship between the government and the firm. In order to achieve this, it is necessary to look at the interplay between the explicit LCPs and corruption. Explicit LCPs are more likely to be successful in ensuring participation of firms in procurement when it is complemented with adequate monitoring and transparency process. However, in the 
case of weak institutions, explicit LCRs serve as a tool for extracting rent. In order to create jobs, facilitate sales and increase productivity, firms therefore choose to comply with LCRs and to corrupt the authorities. The aim of corrupt activities is to secure a contract on procurement with a government. Thus, explicit LCPs serve as a tool facilitating corruption and increasing firm performance. Therefore we hypothesize:

H2: Explicit LCPs positively moderate the relationship between firm corruption and firm performance.

\section{Empirical methodology}

\subsection{The model}

We investigate a relationship between firm performance, its exposure to explicit LCPs and corruption controlling for different firm level characteristics - including foreign ownership, manager experience, use of IT, firm age and size, engagement with the government. The model allows a closer look at how LCPs may initiate corrupt behavior of firms in Kazakhstan and the role LCPs play in firm size and performance. This study analyzes the relationship between firm performance and corruption, then introduces the LCPs as a channel through which corruption may affect firm performance.

To test our hypotheses, we use fixed effects linear estimation to measure the regional, industry and time effects (Cumming et al. 2014). This enables us to control for unobserved heterogeneity across regions, industries and time in one model. We follow Wallace and Hussain (1969) and Wooldridge (2010) by estimating the regression model given by equation (1) with two-way error component disturbances as in equation (2). $\lambda_{r}$. denotes the unobservable regional effect (Wooldridge 2010), $\lambda_{t}$ denotes the unobservable time effect, $\lambda_{s}$ denotes the unobservable industry effect and $e_{i t}$ is the remainder stochastic disturbance term. Note that 
$\lambda_{i}$ is firm-invariant and accounts for any time-specific effect not included in the regression. For example, it could account for government program intervention year effects that disrupt firm productivity or facilitate LCPs. $\lambda_{t}$ is time invariant and accounts for any region-specific effects, such as culture and informal institutional frameworks. In vector form, our panel data estimation is written as:

$y_{i}=f\left(\beta x_{i}, \theta z_{i}, a_{i}, \mu_{i}\right) \quad i=1, \ldots, \mathrm{N} ; \quad t=1, \ldots, \mathrm{T}$

$u_{i}=\lambda_{r}+\lambda_{t}+\lambda_{s}+\mathrm{e}_{i} \quad r=1, \ldots, \mathrm{R} ; \quad s=1, \ldots, \mathrm{S}$

where $y_{i}$ is employment growth, sales growth in a given firm $i . \beta$ and $\theta$ are parameters to be estimated, $x_{i}$ is a vector of independent explanatory variables (firm corruption and LCPs) and $z_{i}$ is a vector of exogenous firm and regional level control variables; $a_{i}$ presents the interaction of firms which secured government contracts with the firm corruption indicator by firm $i$. As mentioned above, the error term $u_{i}$ consists of unobserved regional, industry and time specific effects and other disturbance. $e_{i}$ is independent and identically distributed.

\subsection{Data}

We tested our hypotheses with the fourth and fifth round of the EBRD-World Bank Business Environment and Enterprise Performance Survey (BEEPS) also known as the World Bank Enterprise Survey ${ }^{1}$. This survey is designed to study the impact of government policies on business activity (Fries et al. 2003) and involves face-to-face interviews with high-level firm managers or owners (Hellman et al. 2003). BEEPS firm-level data was matched with regional data (Azhgaliyeva et al. 2017). The surveys were administered using the Enterprise Surveys Global Methodology, which was the same for 2009 and 2013 in Kazakhstan. (http://www.enterprisesurveys.org, The World Bank). The primary sampling unit of the study is the establishment. An establishment is a physical location where business is carried out and

\footnotetext{
${ }^{1} \mathrm{http}: / /$ ebrd-beeps.com/ and http://www.enterprisesurveys.org. Note that the data are no longer collected every three years, the gap is now larger.
} 
where industrial operations take place or services are provided. A firm may be composed of one or more establishments. For the purposes of this survey an establishment makes its own financial decisions and have its own financial statements separate from those of the firm. An establishment also has its own management and control over its payroll. Small firms are establishments with the number of employees of 1 to 19 persons. Medium firms are establishments with the number of employees of 20 to 99 persons. Large firms are establishments with the number of employees of 100+ persons (World Bank, 2009; 2013). Altogether small and medium firms represent around 90\% of the two samples (2009 and 2013), where small firms (1 to 19 persons) represent $45-50 \%$ of the two samples. These figures are in line with the share of small firms in the Kazakhstani economy. The number of observations in 2009 were 544; 2012/13 were 600. The Enterprise Surveys (Kazakhstan) were conducted across all geographic regions (oblasts) and cover small, medium, and large firms. The surveys are administered to a representative sample of firms in the non-agricultural formal private economy and includes the manufacturing, services sector, transportation and construction sectors. However, public utilities, government services, health care, and financial services sectors were not included in the sample. Enterprise Surveys collect a wide array of qualitative and quantitative information through face to face interviews with firm managers and owners regarding the business environment in Kazakhstan and the productivity of their firms. The topics covered in Enterprise Surveys include infrastructure, trade, finance, regulations, taxes and business licensing, corruption, crime and informality, finance, innovation, labor, and perceptions about obstacles to doing business. (World Bank 2009, 2013).

As a preliminary data screening procedure we performed a multicollinearity test. This examined the variance inflation factors for all variables, finding each less than 10 . Thus we have low severity of a multicollinearity problem. In addition, the Pearson correlation coefficients were examined, with all of them being statistically significant in a full sample at 
$5 \%$ significance level and $p<0.70$ to address multicollinearity concerns. We analysed all variables histograms and found that the errors are independent and identically distributed with constant variance. In the presence of multicollinearity the variance is greater and this affects standard errors.

\subsection{Variables}

Dependent variables

We develop two distinctive models with two dependent variables: (i), employment growth over 3 years (change in the number of employees over the three year period before the report year); (ii) sales growth over 3 years (change in total sales over the three year period before the report year).

Above named dependent variables are used in the literature which relates corruption with firm performance (Mohammadi Khyareh 2017; Wiseman 2015; Rodriguez et al. 2005; Shleifer \& Vishny 1993), in particular in developing and transition economies (Estrin et al. 2013; Festus et al. 2014). 
Fig. 1 provides the distribution of sales growth, employment growth and corruption across Kazakhstani companies.
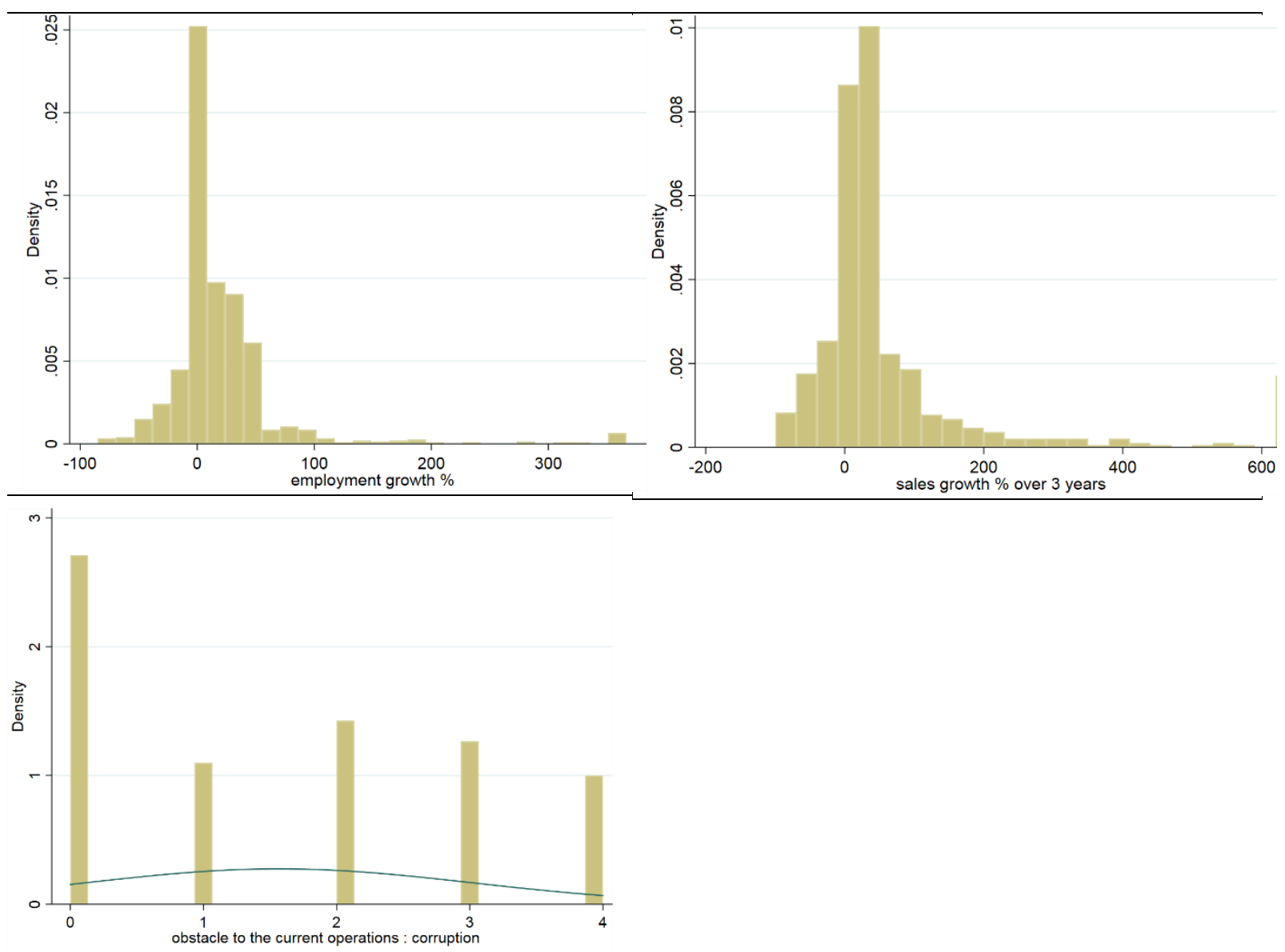

Fig. 1. The distribution of the two dependent variables across Kazakhstani firms Number of obs.: 933

Source: World Bank Enterprise data available at: http://ebrd-beeps.com

Data sources and a description of variables are provided in Table 1.

\section{Table 1}

Descriptive statistics of variables included in the study

\begin{tabular}{|c|c|c|c|c|c|}
\hline Variable & Description & Mean & $\begin{array}{c}\text { St. } \\
\text { dev. }\end{array}$ & Min & Max \\
\hline employment & Employment growth over 3 last years, \% & 18.82 & 51.86 & -85.00 & 366.67 \\
\hline
\end{tabular}




\begin{tabular}{|c|c|c|c|c|c|}
\hline sales growth & Sales growth over 3 last years, $\%$ & 76.04 & 159.8 & -99.83 & 650.00 \\
\hline Age & Age of firm, years & 10.69 & 7.64 & 1.00 & 86.00 \\
\hline foreign & Share of firm owned by a foreign company (investor) & 3.53 & 17.05 & 0.00 & 100.00 \\
\hline state & Share of firm owned by public company (government) & 0.37 & 4.74 & 0.00 & 90.00 \\
\hline certificate & $\begin{array}{l}\text { Firm has an internationally recognized quality certification }=1,0 \\
\text { otherwise }\end{array}$ & 0.82 & 0.39 & 0.00 & 1.00 \\
\hline manager & Top manager years of experience & 13.48 & 9.69 & 1.00 & 50.00 \\
\hline female $C E O$ & Top manager female $=1,0$ otherwise & 0.23 & 0.42 & 0.00 & 1.00 \\
\hline email & Email is used to communicate value $=1,0$ otherwise & 0.83 & 0.37 & 0.00 & 1.00 \\
\hline$W e b$ & Website is used to communicate value $=1,0$ otherwise & 0.42 & 0.49 & 0.00 & 1.00 \\
\hline $\begin{array}{l}\text { government } \\
\text { contract }(H 2)\end{array}$ & Government contract secured in the last 12 months $=1,0$ otherwise & 0.67 & 0.42 & 0.00 & 1.00 \\
\hline $\begin{array}{l}\text { corruption } \\
\text { index }(H 1)\end{array}$ & $\begin{array}{l}\text { Administrative burden adjustment index standardised measure } \\
\text { calculated using Cronbach alpha , }-2.5 \text { smallest to } 2.5 \text { greatest } \\
\text { adjustment (authors' calculation) }\end{array}$ & -0.13 & 0.54 & -1.36 & 1.94 \\
\hline corruption & $\begin{array}{l}\text { How much of the obstacle was corruption: zero - not an obstacle; } \\
4 \text { - severe obstacle }\end{array}$ & 1.56 & 1.45 & 0 & 4 \\
\hline
\end{tabular}

Note: number of obs. 933.

Source: fourth and fifth round of the EBRD-World Bank Business Environment and Enterprise Performance Survey (BEEPS) available at: http://ebrd-beeps.com

\section{Explanatory variables}

Our first explanatory variable is firm corruption. Corruption can affect firm performance both positively and negatively. We use two independent proxies: corruption index and corruption as an obstacle, both taken from the World Bank Surveys $(2009,2013)$. corruption index includes the cost to firms in terms of the number of meetings requested by tax officials, time spent on dealing with government regulations, gifts/informal payments to officials, perceived barriers to doing business as corruption, and informal payments (Kaufmann and Wei 2000). For the robustness check we use the second indicator of corruption - corruption as an obstacle of doing business (from 0 to 4 ). The difference between these two variables is the regulatory burden faced by a firm.

The World Bank $(2009,2013)$ report rich statistics on the varieties of practices of informal sector, namely, $26.7 \%$ of surveyed firms reported bribery incidence (percent of firms experiencing at least one bribe payment request); $22 \%$ of surveyed firms reported bribery depth (\% of public transactions where a gift or informal payment was requested), $22.3 \%$ of firms 
expected to give gifts in meetings with tax officials; $19.1 \%$ are expected to give gifts to secure government contract.

The firms may have provided the "socially acceptable response". To construct the corruption index we used Cronbach alpha approach with the index being equal to (0.75) (Cronbach 1951; Wooldridge 2010) using data from the World Bank Enterprise Survey.

Our survey demonstrates that overall, firms that engage in bribes spent, on average, $6.9 \%$ of sales on bribes (up to a maximum of 50\%). Firms that pay bribes in order to secure contracts spent on average $11.6 \%$ of the contract value (up to a maximum of $30 \%)^{2}$. Only $63 \%$ of firms said that they did not pay bribes in order to secure contracts. Interestingly, only 203 firms out of 933 responded to that question. Tax officials requested gifts from one out of six firms. On average senior managers spent $7.5 \%$ of their time dealing with regulations and $41 \%$ of firms had been inspected in the previous 12 months. Firms consider tax rates and corruption as the greatest obstacles for business.

Our second explanatory variable is LCPs proxy by government contract, a binary variable, which equals one if a firm secured a government contract during the last 12 months, zero otherwise. Securing a government contract is a firm-level indicator which is ad hoc for a firm. An increase in LCRs such as number of employees, local products, resources, inputs, local capital, land etc. increases the likelihood of securing a contract. We argue that securing a government contract is a form of explicit LCP, i.e., the LCP affected Kazakhstani firms' procurement of government contracts. LCP does help Kazakhstani companies win contracts if there is no international competition. The government, ceteris paribus, is likely to give a contract to a firm which has a higher composition of LC inputs in their value creation (see Fig. 2 in Flaig and Stone 2017). Various types of contracts and competitions based on LCRs

\footnotetext{
${ }^{2}$ The bribe to secure government expenditure is often calculated as a share of contract value (Soreide 2002).
} 
continue to pave a way to boost domestic industry without incurring significant fiscal outlay. By mandating local sourcing of goods and services through the government contracts, this indicator at a firm level is able to capture the extent of the firm's engagement in compliance with LCRs.

\section{Control variables}

We control for firm-level variables (firm characteristics and managerial characteristics) as well as year, industry and regional fixed effects.

Firm-level characteristics include: firm size and age, whether the firm has internationally recognized quality certificate, the chief executive officer's characteristics (experience and gender), whether the firm uses IT (web or email) for communications with suppliers or customers, corruption index, share of foreign ownership and share of public ownership. We identify the industry where a firm operates and the region where it is located. In this data set Kazakhstan is divided into 5 geographical regions.

Firm-level data includes firms from 14 industries (Table 2) with most of them in retail trade and a few in textile. Firms are from all five geographical regions in Kazakhstan with the majority of firms from the south $(32 \%)$ and north $(24 \%)$. The sample includes small ( $<20$ fulltime employees (FTEs)), medium (20-99 FTEs) and large firms (>99 FTEs). However, most firms are small $(40 \%)$ or medium (40\%). The average of firm corruption is within 20 percent deviation from the average corruption index across all sectors in Kazakhstan. This is consistent with Estrin et al (2013) who described the institutional environment which is likely to be pathdependent within the same country: hence, we are unlikely to see differences in corruption level within the same institutional environment, such as a country.

\section{Table 2}

Industry distribution and firm performance 


\begin{tabular}{lcccc}
\hline \multicolumn{1}{c}{ Industry } & Firms & $\begin{array}{c}\text { Average, } \\
\text { employment } \\
\text { growth, } \%\end{array}$ & $\begin{array}{c}\text { Average sales } \\
\text { growth, } \%\end{array}$ & $\begin{array}{c}\text { Average } \\
\text { corruption } \\
\text { index }\end{array}$ \\
\hline Textiles & 6 & -7.07 & 29.82 & -0.18 \\
Garments & 25 & 24.67 & 115.99 & 0.04 \\
Food & 89 & 18.12 & 79.87 & -0.10 \\
Metals and machinery & 62 & 7.12 & 53.89 & -0.03 \\
Electronics & 18 & 20.75 & 117.98 & -0.05 \\
Chemicals and pharmaceuticals & 10 & 9.92 & 117.75 & -0.14 \\
Wood and furniture & 29 & 5.82 & 6.41 & -0.41 \\
Non-metallic and plastic materials & 60 & 15.71 & 61.72 & -0.17 \\
Auto and auto components & 2 & 25.29 & 22.41 & -0.28 \\
Other manufacturing & 81 & 22.38 & 94.75 & -0.13 \\
Retail and wholesale trade & 313 & 19.46 & 76.76 & -0.14 \\
Hotels and restaurants & 19 & 24.67 & 41.37 & -0.18 \\
Other services & 89 & 10.56 & 61.55 & -0.18 \\
Other: Construction, Transportation, etc. & 130 & 30.12 & 86.23 & -0.05 \\
\hline
\end{tabular}

Source: fourth and fifth round of the EBRD-World Bank Business Environment and Enterprise Performance Survey (BEEPS) available at: http://ebrd-beeps.com

\section{Results}

Our main results are reported in Table 3 and Fig. 2. Table 3 includes both basic models for fixed effect estimation (columns (1), (3) and (5)) and the model with interaction terms (columns (2), (4) and (6)). The signs of the coefficients and confidence intervals between both models are similar, although the significance of the coefficients is stronger when estimated with all controls and interactions.

\section{Table 3}

Fixed effects estimation of firm performance using two models

\begin{tabular}{|c|c|c|c|c|}
\hline \multirow{3}{*}{ Independent variable } & \multicolumn{2}{|c|}{ Model 1} & \multicolumn{2}{|c|}{ Model 2} \\
\hline & \multicolumn{2}{|c|}{ Employment growth } & \multicolumn{2}{|c|}{ Sales growth } \\
\hline & (1) & (2) & (3) & (4) \\
\hline age & $\begin{array}{c}-2.083 * * \\
(0.92)\end{array}$ & $\begin{array}{c}-2.028 * * \\
(0.81)\end{array}$ & $\begin{array}{c}-3.270^{*} \\
(2.01)\end{array}$ & $\begin{array}{c}-3.231 * * \\
(1.95)\end{array}$ \\
\hline age squared & $\begin{array}{c}0.0232 * * \\
(0.01)\end{array}$ & $\begin{array}{c}0.0231 * * \\
(0.01)\end{array}$ & $\begin{array}{c}0.124 * * \\
(0.05)\end{array}$ & $\begin{array}{c}0.114 * * \\
(0.05)\end{array}$ \\
\hline foreign & $\begin{array}{c}-0.081 * \\
(0.05)\end{array}$ & $\begin{array}{c}-0.091^{* *} \\
(0.05)\end{array}$ & $\begin{array}{l}0.372 \\
(0.69)\end{array}$ & $\begin{array}{l}0.390 \\
(0.70)\end{array}$ \\
\hline state & $\begin{array}{l}-0.178 \\
(0.17)\end{array}$ & $\begin{array}{l}-0.180 \\
(0.15)\end{array}$ & $\begin{array}{l}0.528 \\
(1.24)\end{array}$ & $\begin{array}{l}0.325 \\
(1.28)\end{array}$ \\
\hline certificate & $\begin{array}{l}5.543 \\
(6.09)\end{array}$ & $\begin{array}{l}10.601 \\
(8.06)\end{array}$ & $\begin{array}{c}20.99 \\
(16.55)\end{array}$ & $\begin{array}{c}22.21 \\
(17.45)\end{array}$ \\
\hline manager & $\begin{array}{c}-0.533 * * * \\
(0.20)\end{array}$ & $\begin{array}{c}-0.602 * * * \\
(0.20)\end{array}$ & $\begin{array}{l}-0.335 \\
(0.83)\end{array}$ & $\begin{array}{l}-0.369 \\
(0.85)\end{array}$ \\
\hline
\end{tabular}




\begin{tabular}{|c|c|c|c|c|}
\hline female & $\begin{array}{l}-2.142 \\
(5.14)\end{array}$ & $\begin{array}{l}-1.983 \\
(5.15)\end{array}$ & $\begin{array}{l}-6.623 \\
(14.32)\end{array}$ & $\begin{array}{l}-8.454 \\
(13.99)\end{array}$ \\
\hline email & $\begin{array}{c}15.112 * * \\
(6.18)\end{array}$ & $\begin{array}{c}14.421 * * \\
(5.85)\end{array}$ & $\begin{array}{c}21.534 * \\
(14.58)\end{array}$ & $\begin{array}{c}21.611 * * \\
(14.37)\end{array}$ \\
\hline web & $\begin{array}{c}12.630 * \\
(7.26)\end{array}$ & $\begin{array}{c}10.470 * \\
(6.65)\end{array}$ & $\begin{array}{c}38.690 * * * \\
(13.29)\end{array}$ & $\begin{array}{c}37.570 * * * \\
(13.41)\end{array}$ \\
\hline corruption index (H1) & $\begin{array}{c}7.210 * * \\
(4.00)\end{array}$ & $\begin{array}{c}27.770 * * \\
(13.58)\end{array}$ & $\begin{array}{l}16.040 \\
(15.34)\end{array}$ & $\begin{array}{c}0.941 \\
(22.80)\end{array}$ \\
\hline year fixed effect & $\begin{array}{c}-21.400 * * * \\
(5.91)\end{array}$ & $\begin{array}{c}-22.170 * * * \\
(5.94)\end{array}$ & $\begin{array}{c}-91.880 * * * \\
(13.13)\end{array}$ & $\begin{array}{c}-92.92 * * * \\
(13.53)\end{array}$ \\
\hline government contract & & $\begin{array}{c}-18.041 * \\
(10.13)\end{array}$ & & $\begin{array}{l}-20.371 \\
(17.41)\end{array}$ \\
\hline government contract $\mathrm{x}$ corruption index $(\mathbf{H} 2)$ & & $\begin{array}{l}-29.871 \\
(21.90)\end{array}$ & & $\begin{array}{c}20.331 * * \\
(12.71)\end{array}$ \\
\hline industry \& region fixed effects & Yes & Yes & Yes & Yes \\
\hline Constant & $\begin{array}{c}23.15 \\
(19.01)\end{array}$ & $\begin{array}{c}32.52 \\
(21.19)\end{array}$ & $\begin{array}{l}67.32 * \\
(35.82)\end{array}$ & $\begin{array}{c}69.14 * * \\
(34.46)\end{array}$ \\
\hline $\mathrm{N}$ obs. & 933 & 933 & 933 & 933 \\
\hline R-squared & .118 & .148 & .171 & .205 \\
\hline RMSE & 49.84 & 49.28 & 122.34 & 122.83 \\
\hline F-statistics & 2.94 & 2.55 & 4.02 & 3.05 \\
\hline Log likelihood & -4958.26 & -4888.21 & -3816.09 & -3786.33 \\
\hline
\end{tabular}

Standard errors robust for heteroscedasticity are in parentheses. $* * * p<0.01$, ** $p<0.05, * p<0.1$. Regional fixed effects, industry fixed effects are suppressed to save space. Reference industry=Textiles; Reference Region=Central; Reference year=2009.

Source: fourth and fifth round of the EBRD-World Bank Business Environment and Enterprise Performance Survey (BEEPS) available at: http://ebrd-beeps.com

We interpret our findings using the predictive margins (Fig. 2). The left column of Fig. 2 contains the results for the firms which secured government contracts as form of LCPs, whereas the right column represents the results for firms that did not secure government contracts. 


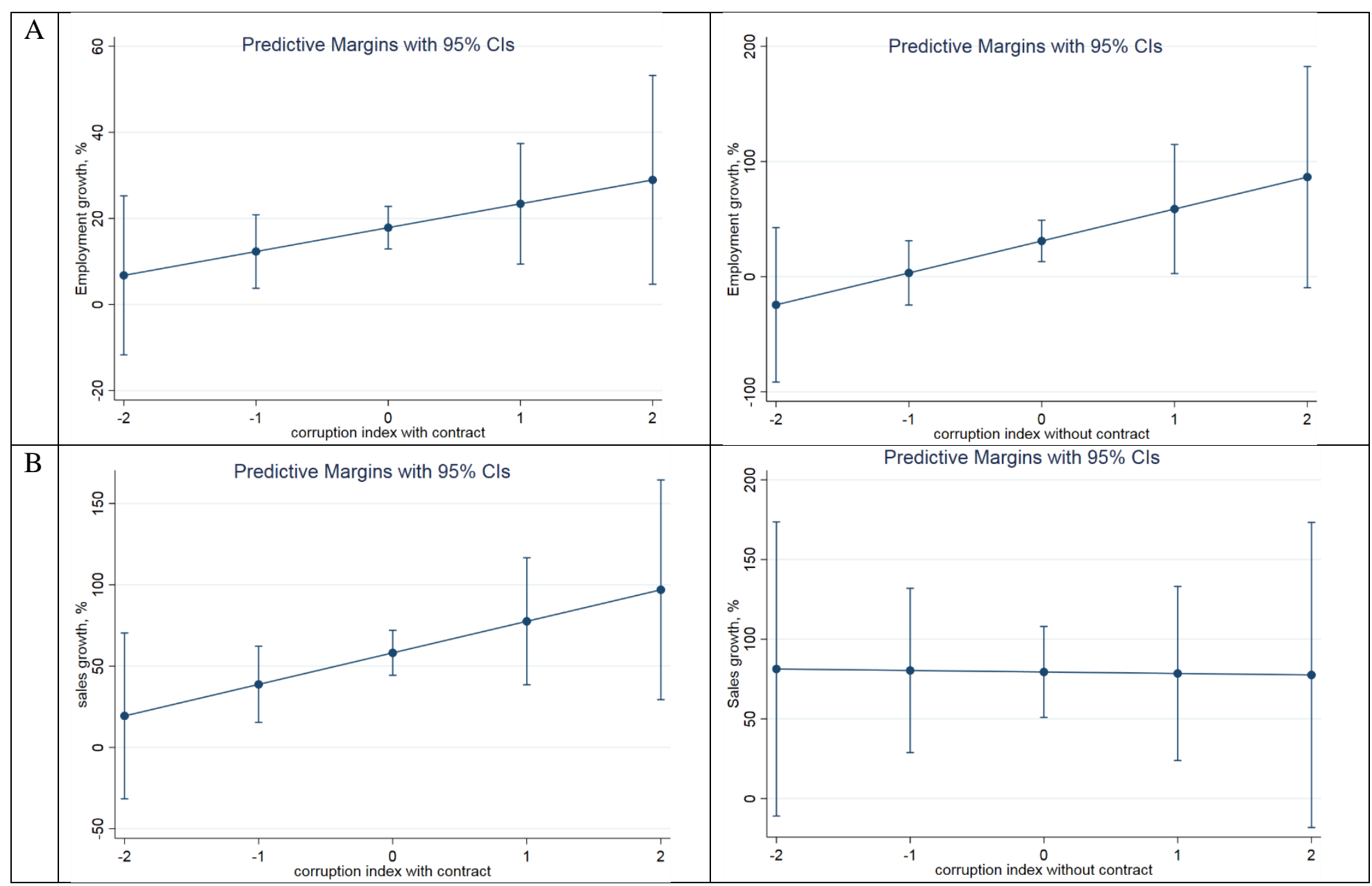

Fig. 2. The moderating effect of local content policy in the relationship between corruption and firm performance

Number of obs.: 933

Source: fourth and fifth round of the EBRD-World Bank Business Environment and Enterprise Performance Survey (BEEPS) available at: http://ebrd-beeps.com

The post-estimation predictive margins (Fig.2) were calculated based on Models 1-2 for columns: 2 and 4 (Table 3). We used the margins command in a statistical software STATA 15 to compute the standard errors of the means. The marginsplot command was used afterward as it gives a good view of the shape of the relationship and its economic significance (Williams 2012). It illustrates the changes in the marginal effect between independent variables (corruption and LCPs) and each of the two dependent variables (employment growth and sales growth). For example, from Fig. 2(A) (left column) the predictive margins allow us to measure the employment growth as the level of firm corruption changes for firms which secured a 
government contract. So the increase in corruption from 0 to 2 (twice effect) increases the employment growth from 20 to 30 per cent for firms which secure the contracts.

Our $\mathbf{H 1}$ is partially supported. The increase in firm corruption positively relates to the increase in employment growth with the values between $(7.21-27.77, \mathrm{p}<0.05)$ (Table 3 columns (1)-(2)). This shows that one unit increase in corruption index is associated with higher firm employment growth (28\%). Table 3 specification 1 demonstrates that increase in corruption is positively associated with job creation, approximately 7\%, while controlling for government contracts the coefficient of corruption increases and remain positive and significant. Government contracts are negatively associated with job growth which means that they are not labour intense. The distribution of corruption index across Kazakhstani firms lies in the interval $[-2 ; 2]$. The economic importance of this finding suggests that a move from a lower (first) quartile to a middle (second) quartile increases a firm's employment growth at a maximum of 27.7 per cent.

We found no association between firm corruption and sales growth (Table 3 columns (3)-(4)). Firms that are more corrupt have higher employment growth, but per se corruption is inefficient in driving market sales and productivity (Aidis et al. 2012). As pointed out by Francis and Schweiger (2017) “...the presence of selectively applied measures or positions that alter the cost of exporting for some (or similarly the breakout cost of entry)" [and] "Selective access to cost-reducing mechanisms - including subsidies, credit lines, privileged access to licencing and resources, or export promotion" (Francis and Schweiger 2017:190) is likely to decrease firm's premia. We have also found this to be the case with Kazakhstani firms.

Our $\mathbf{H 2}$ is fully supported. Securing government contracts becomes an efficient conduit of corruption for sales growth, unlike employment growth. LCPs positively moderate the effect of corruption on firms' performance by "greasing the wheels" of business in emerging economies (Chowdhury et al. 2015; Kalyuzhnova et al. 2016). 
The results demonstrate that the level of influence of corruption on firms' performance is conditional on engagement with the government on various policies (e.g. LCPs).

Table 4 estimates (1) with the proxy for firm corruption as 'corruption as obstacle' instead of corruption index. Other variables remain unchanged.

Table 4 Fixed effects estimation of firm performance using two models

\begin{tabular}{lcccc}
\hline \multirow{2}{*}{ Independent variable } & Model 1 & Model 2 & Model 3 & Model 4 \\
\cline { 2 - 4 } & \multicolumn{2}{c}{ Employment growth } & Sales growth \\
\hline corruption as obstacle (H1) & $(1)$ & $(2)$ & $(3)$ & $(4)$ \\
government contract & $2.42^{* *}$ & $470^{* *}$ & $17.45^{*}$ & $1.24^{*}$ \\
& $(4.00)$ & $(13.58)$ & $(5.14)$ & $(22.80)$ \\
government contract x corruption as obstacle & & $-17.04^{*}$ & & -13.31 \\
(H2) & & $(9.13)$ & $(11.01)$ \\
industry \& region fixed effects & & $2.38^{* *}$ & & $17.33^{* *}$ \\
Other controls unchanged (Table 3) & & $(0.95)$ & $(12.71)$ \\
\hline Constant & Yes & Yes & Yes & Yes \\
N obs. & Yes & Yes & Yes & Yes \\
R-squared & 24.25 & 28.22 & $45.32^{*}$ & $44.14^{* *}$ \\
RMSE & $(16.01)$ & $(14.19)$ & $(25.82)$ & $(24.46)$ \\
F-statistics & 933 & 933 & 933 & 933 \\
Log likelihood & .126 & .166 & .198 & .232 \\
\hline
\end{tabular}

Standard errors robust for heteroscedasticity are in parentheses. $* * * p<0.01$, ** $p<0.05, * p<0.1$. Regional fixed effects, industry fixed effects are suppressed to save space. Reference industry=Textiles; Reference Region=Central; Reference year=2009.

Source: fourth and fifth round of the EBRD-World Bank Business Environment and Enterprise Performance Survey (BEEPS) available at: http://ebrd-beeps.com

Having run the robustness check we found additional evidence for the relationship between firm corruption and performance (H1). The increase in firm corruption positively relates to the increase in employment growth $(2.42-4.7, \mathrm{p}<0.05)$ (Table 4 columns $(1)-(2))$. This shows that one unit change in the perception of corruption as being an obstacle for doing business (e.g. moving from no obstacle zero to minor obstacle one) is associated with an increase in employment growth by $2.42-4.70 \%$. Table 4 specification 1 demonstrates that increase in 
corruption is positively associated with job creation, while controlling for government contracts shows that the coefficient of corruption remains positive and significant. The economic importance of this finding suggests that perception of corruption as a greater obstacle is likely to be associated with higher employment growth.

The increase in firm corruption positively relates to the increase in sales growth $(1.24$ to $17.45 \%, \mathrm{p}<0.05)$ (Table 4 columns (3)-(4)). Firms that perceive corruption as an obstacle exhibit higher sales growth with the major effect from securing government contracts (1.24+ $17.33=18.57, \mathrm{p}<0.05)$.

The interaction coefficients between government contracts and firm corruption in Table 4 illustrate that explicit LCPs positively moderate the relationships between corruption and job growth $(2.38, \mathrm{p}<0.05)$ as well as between corruption and sales growth $(17.33, \mathrm{p}<005)$, supporting H2. In case of securing a government contract, corruption will have a larger effect on sales growth than on job growth.

As part of the robustness check for the sample representativeness we used svy command in STATA 15, and found that regression coefficients and predictive margins have not changed their signs, significance and confidence intervals. We are using the sampling weight on the stratified samples of 544 firms in 2009) and 600 firms in 2013 of the World Bank Survey, which is applied to weight the sample back to the population of firms from which the sample was drawn. For each representative firm (2009) in the sample of 544 observations, the population of firms varies between 86 to 6565 firms. For each representative firm (2013) in the sample of 600 observations, the population of firms varies between 87 to 9213 firms. The variable we used for weighting was provided by the World Bank Survey called 'stratified weight', which was applied as a probability weight. The probability weight, called a pweight in Stata, is calculated as $\mathrm{N} / \mathrm{n}$, where $\mathrm{N}=$ the number of elements in the population and $\mathrm{n}=$ the number of elements in the sample. For example, in our case, if a population of firms has 47328 
firms with similar characteristics in 2013 and 544 are sampled at random with replacement, then the probability weight would be $47328 / 544=87$.

\section{Discussion and Conclusion}

At the present time there is limited knowledge of the impact of explicit LCPs on firm performance and their links with corruption. Our study examines the effect of LCPs in moderating the relationship between corruption and firm performance, using the firm-level data on Kazakhstan.

In this paper we investigated the dichotomy of the explicit LCPs implementations. This study makes the following contributions to economic systems literature. First, we estimate the impact of corruption on different types of firm performance, including sales growth and employment growth. We found that the relationship between corruption and various types of firm performance is idiosyncratic (Rodriguez et al. 2005; Shleifer \& Vishny 1993; Estrin et al. 2013; Belitski et al. 2016). Second, using the World Bank Enterprise Survey between 2009 and 2013, based on firm-level face-to-face interviews, we were able to measure the impact of corruption on firm performance in Kazakhstan and the role that explicit LCPs play as a facilitator of this relationship.

Our findings challenge and expand the results for other developing economies (Heum et al. 2003; Nwapi 2015; Ovadia 2014; Francis and Schweiger 2017) and capture the role of explicit LCPs plays in firm performance.

Based on the evidence from Kazakhstan we provide a positive answer to the question of whether building a special relationship with authorities facilitates better returns from corruption. This study opens a conversation on the effect of corruption on the micro level as "greasing the wheels" for firm size and "sanding the wheels" for firm productivity. In addition, 
we spell out the new policies which are required when building a special relationship with government while securing a contract.

The limitations of this study are: firstly, we only measure the corrupt transactions linked with informal interactions between the firm and the authorities and the perception about corruption as an obstacle in doing business. This does not always truly reflect the multifaceted phenomenon of corruption. Secondly, our sample of firms is rotated, which does not allow us fully to investigate the dynamics of corrupt behaviour and the time response to the introduction of explicit LCPs for firm performance. Thirdly, we only capture the ability of the firm to secure a contract with the government as a proxy for explicit LCPs. This does not always represent the full spectrum of the explicit LCPs available for government use. The process of investigating risks which are related to implementation of explicit LCPs in emerging economies is a very complex problem due to the fact that it is hard to monitor, to audit and to detect both firm corruption and firm compliance with explicit LCPs.

One of the important policy recommendations arising from this study is that the governments using the LC instrument should be aware of the potential risks related to corrupt activities. The failure of explicit LCPs is often explained by the fact that the corruption opportunities have triggered a lack of transparency in the implementation of such LCPs. There are clear disincentives caused by the conjunction of LCPs and corruption for companies planning to invest to such economies. It sends a bad signal about the quality of the economic system in which the given LCPs is implemented.

In order to increase competitiveness, the Kazakhstani government is in need of designing a strategy which would take into consideration the particular pillars supporting local firms. Until 2021(the end of WTO transition period) this will include both protectionist measures (in the form of explicit LCPs) and competition policy. Further research will consider the question of different LCPs roles in facilitating the competitiveness of firms and of 
Kazakhstani economy in general, before and after 2021. The experience of some resource-rich countries demonstrates that in some cases, LCPs can stimulate domestic product development and exports; other cases show that LCPs can become an impediment to the achievement of competitiveness (Kalyuzhnova, et.al. 2016). At the present time, in order to improve the governance of LCP implementation, Kazakh National Agency on Local Content (NADLoc) needs to create an enforcement unit with a high level of authoritative capacity in order to monitor, evaluate and enforce compliance. To ensure the benefits of LCPs, transparency has to be promoted and be linked to a stable and predictable business environment for foreign and domestic firms. This implies that the implementation of the policy needs to be closely monitored to ensure its efficacy in enabling the increase of firms' performance. 


\section{References}

Acemoglu, D. and Verdier, T., 2000. The choice between market failures and corruption. American economic review, 90(1), pp.194-211.

Aidis, R., Estrin, S., \& Mickiewicz, T. M., 2012. Size matters: entrepreneurial entry and government. Small Business Economics, 39(1), 119-139.

Aidt, T. S. 2016. Rent seeking and the economics of corruption. Constitutional Political Economy, 27(2), 142-157.

An, G., Becker, C. M., \& Cheng, E. 2017. Economic Crisis, Income Gaps, Uncertainty, and Inter-regional Migration Responses: Kazakhstan 2000-2014. The Journal of Development Studies, 53(9), 1452-1470.

Athanasouli, D., Goujard, A., \& Sklias, P. 2012. Corruption and firm performance: evidence from Greek firms. International Journal of Economic Sciences and Applied Research, 5(2), 43-67.

Azhgaliyeva, D., Belitski, M., Kalyuzhnova, Y. 2017. Kazakhstan Regional Data 1994-2014. University of Reading. Dataset. http://dx.doi.org/10.17864/1947.115.

Becker, G. S., and Stigler, G. J. 1974. Law enforcement, malfeasance, and compensation of enforcers. The Journal of Legal Studies, 3(1), 1-18.

Belitski, M., Chowdhury, F., \& Desai, S., 2016. Taxes, corruption, and entry. Small Business Economics. doi: 10.1007/s11187-016-9724-y.

Bicchieri, C., \& Duffy, J., 1997. Corruption cycles. Political Studies, 45(3), 477-495.

Bicchieri, C., \& Rovelli, C., 1994. The Dynamics of Corruption. CMU report PHIL-57, Carnegie Mellon University, Pittsburg.

Chowdhury, F., Desai, S., Audretsch, D. B., \& Belitski, M., 2015. Does corruption matter for international entrepreneurship? International Entrepreneurship and Management Journal, 11(4), 959-980.

Cronbach, L. J., 1951. Coefficient alpha and the internal structure of tests. Psychometrika, 16(3), 297-334.

Cumming, D., Johan, S., \& Zhang, M. 2014. The economic impact of entrepreneurship: Comparing international datasets. Corporate Governance: An International Review, 22(2), 162-178.

Djankov, S., 2009. The regulation of entry: a survey. The World Bank Research Observer, 24(2), 183-203.

Djankov, S., La Porta, R., Lopez-de-Silanes, F., \& Shleifer, A., 2002. The regulation of entry. Quarterly Journal of Economics, 117(1), 1-37.

Dutta, N. and Sobel, R., 2016. Does corruption ever help entrepreneurship?. Small Business Economics, 47(1), pp.179-199. 
Estrin, S., Korosteleva, J. \& Mickiewicz, T., 2013. Which institutions encourage entrepreneurial growth aspirations? Journal of Business Venturing, 28(4), 564-580.

Festus, N., Bassey, G.E. and Uyang, F.A., 2014. Entrepreneurship, Corruption and the Challenge of Development In Nigeria. Eur. J. Bus. Soc. Sci, 3(3), pp.104-112.

Flaig, D \& Stone, S.F., 2017. Local Content Requirements Versus Tariff Equivalents: How We Measure Matters. The World Economy, doi: 10.1111/twec.12426.

Francis, D.C. and Schweiger, H., 2017. Not so different from non- traders. Economics of Transition, 25(2), pp.185-238.

Fries, S., Lysenko, T., \& Polanec, S., 2003. The 2002 business environment and enterprise performance survey: results from a survey of 6,100 firms. European Bank for Reconstruction and Development, Working Paper No. 84.

Glaeser, E.L. and Saks, R.E., 2006. Corruption in America. Journal of public Economics, 90(67), pp.1053-1072.

Hallward-Driemeier, M., Wallsten, S., \& Xu, L. C., 2006. Ownership, investment climate and firm performance. Economics of Transition, 14(4), 629-647.

Hellman, J. S., Jones, G., \& Kaufmann, D., 2003. Seize the state, seize the day: state capture and influence in transition economies. Journal of Comparative Economics, 31(4), 751-773.

Heum, P., C. Quale, J. E. Karlsen, M. Kragha, and J. Osahon., 2003. "Enhancement of Local Content in the Upstream Oil and Gas Industry in Nigeria." SNF Report No.25/03. Institute for Research in Economics and Business Administration, Kragha \& Associates and Rogaland Research.

Kalyuzhnova Y., Nygaard, C.A., Omarov, Y., \& Saparbayev, A., 2016. Local Content Policies in Resource Rich Countries. Basingstoke, Hampshire: Palgrave MacMillan.

Kalyuzhnova, Y., 2008. Economics of the Caspian oil and gas wealth: Companies, governments, policies. Springer.

Kalyuzhnova, Y., Kutan, A., \& Yigit, T., 2009. Corruption and economic development in energy-rich economies. Comparative Economic Studies, 51(2), 165-180.

Kaufmann, D., \& Wei, S.-J., 2000. Does "grease money" speed up the wheels of commerce? International Monetary Fund Policy Working Paper WP/00/64.

Kolstad I. and A. Kinyondo, 2017. Alternatives to local content requirements in resource-rich countries, Oxford Development Studies, 45:4, 409-423.

Lambsdorff, J. G. 2002. Corruption and rent-seeking. Public Choice, 113(1-2), 97-125.

Lambsdorff, J.G., 2003. How corruption affects productivity. Kyklos, 56(4), pp.457-474.

Lein, D-H D. 1986. “A note on competitive bribery games”, Economics Letters 22(4), 337341. 
Lien, D. H. D., 1990. Corruption and allocation efficiency. Journal of Development Economics, 33(1), 153-164.

Martini, M. 2014. Local Content Policies and Corruption in the Oil and Gas Industry.U4AntiCorruption Resource Centre, September 2014. Available at: http://www.u4.no/publications/local-content-policies-and-corruption-in-the- oil-and-gasindustry/. Accessed 15 May 2018.

McArthur, J., \& Teal, F., 2002. Corruption and Firm Performance in Africa. Oxford: University of Oxford.

Mendoza, R.U., Lim, R.A. and Lopez, A.O., 2015. Grease or sand in the wheels of commerce? Firm level evidence on corruption and SMEs. Journal of International Development, 27(4), pp.415-439.

Méon, P. G., \& Sekkat, K. 2015. The formal and informal institutional framework of capital accumulation. Journal of comparative economics, 43(3), 754-771.

Meon, P-G and Weill L., 2010. Is corruption an efficient grease?, World Development 38(3), 244-259.

Mohammadi Khyareh, M., 2017. Institutions and entrepreneurship: the mediating role of corruption. World Journal of Entrepreneurship, Management and Sustainable Development, 13(3), pp.262-282.

North, D., 1990. Institutions, institutional change, and economic performance. Cambridge, UK: Cambridge University Press.

Nwapi, C., 2015. Corruption vulnerabilities in local content policies in the extractive sector: an examination of the Nigerian Oil and Gas Industry Content Development Act, 2010. Resources Policy, 46(2015), 92-96.

Ovadia, J. S. 2012. The Dual Nature of Local Content in Angola's Oil and Gas Industry: Development vs. Elite Accumulation. Journal of Contemporary African Studies, 30(3), 395417.

Ovadia, J.S., 2014. Local content and natural resource governance: The cases of Angola and Nigeria. The Extractive Industries and Society, 1(2), 137-146.

Ramdoo, I. 2015. Unpacking local content requirements in the extractive sector: what implications for the global trade and investment frameworks. by International Centre for Trade and Sustainable Development, Geneva, Switzerland.

Rodriguez, P., Uhlenbruck, K., \& Eden, L., 2005. Government corruption and the entry strategies of multinationals. Academy of Management Review, 30(2), 383-396.

Rose-Ackerman, S. and Palifka, B.J., 2016. Corruption and government: Causes, consequences, and reform. Cambridge University Press.

Sahakyan, N., \& Stiegert, K. W., 2012. Corruption and firm performance. Eastern European 
Economics, 50(6), 5-27.

Sarsfield, R. (2012). The bribe game: microfoundations of corruption in Mexico. Justice System Journal, 33(2), 215-234.

Schwab, K. Sala-i-Martín, X. 2015. The Global Competitiveness Report 2015-2016. World Economic Forum.

Shleifer, A. and Vishny, R.W., 1993. Corruption. The quarterly journal of economics, 108(3), pp.599-617.

Søreide, T., 2002. Corruption in public procurement. Causes, consequences and cures. Chr. Michelsen Intitute, Bergen.

Spiller, P. T., 1990. Politicians, interest groups, and regulators: a multiple-principals agency theory of regulation, or "let them be bribed". Journal of Law \& Economics, 33(1), 65-101.

Tonoyan, V., Strohmeyer, R., Habib, M., \& Perlitz, M. 2010. Corruption and entrepreneurship: How formal and informal institutions shape small firm behavior in transition and mature market economies. Entrepreneurship theory and practice, 34(5), 803-832.

Tordo, S., \& Anouti, Y. 2013. Local Content Policies in the Oil and Gas Sector: Case Studies. World Bank Publications.

Treisman, D., 2000. The causes of corruption: a cross-national study. Journal of Public Economics, 76(3), 399-457.

van Stel, A., Storey, D., \& Thurik, A., 2007. The effect of business regulations of nascent and young business entrepreneurship. Small Business Economics, 28(2-3), 171-186.

Wallace, T.D. and Hussain, A., 1969. The use of error components models in combining cross section with time series data. Econometrica: Journal of the Econometric Society, pp.55-72.

Wieneke, A. and Gries, T., 2011. SME performance in transition economies: The financial regulation and firm-level corruption nexus. Journal of Comparative Economics, 39(2), 221229.

Williams, R. 2012. Using the margins command to estimate and interpret adjusted predictions and marginal effects. Stata Journal, 12(2), 308.

Williamson, O. E. 1998. The institutions of governance. The American Economic Review, 88(2), 75-79.

Wiseman, T., 2015. Entrepreneurship, corruption, and the size of US underground economies. Journal of Entrepreneurship and Public Policy, 4(3), pp.313-330.

Wooldridge, J., 2010. Econometric Analysis of Cross Section and Panel Data. MIT Press.

World Bank, 2009. Kazakhstan Country profile 2009. Enterprise Survey. http://www.enterprisesurveys.org/

World Bank, 2013. Kazakhstan Country profile 2013. Enterprise Survey. http://www.enterprisesurveys.org/ 
Xu, G., Zhang, D. and Yano, G., 2017. Can corruption really function as "protection money" and "grease money"? Evidence from Chinese firms. Economic Systems, 41(4), pp.622-638. 